\title{
Metacognitive writing strategies of Sri Lankan secondary school children
}

\section{Godwin Kodituwakku}

Director, Department of Research \& Development, National Institute of Education, Maharagama

\begin{abstract}
This study was conducted to identify metacognitive strategies used by secondary school children in the three stages of writing process, to identify their distribution within metacognitive strands and metacognitive fields, and to identify whether they differ according to rural / urban schools, grades and sex. 408 observation notes, written exercises from 278 Mother Tongue lessons, 289 interviews and responses to a questionnaire were collected from 678 Grade 6-10 students. Qualitative data were coded, frequencies calculated and differences between proportions were $\mathrm{Z}$ tested. Quantitative data were clustered and analyzed using Chi square and Factor analysis. Writing Stage is dominant in the Writing Process of Grades 6 -10 students of both sexes and in rural / urban schools. Planning and Revising stages are mixed with the Writing Stage. The Planning Stage is dominated by an explanation of the lesson by the teacher. Students do not show an awareness or regulation of metacognitive strategies in the Planning of Writing. Knowledge Telling Process can be found in the Writing Stage. Revising Stage is dominated by mechanical and surface level changes. There is a tendency towards a boy-girl dichotomy. Girls emphasize the Planning Stage whereas the boys emphasize the Writing Stage.
\end{abstract}

\section{INTRODUCTION}

Flavell (1976) first coined the term metacognition as “one's knowledge concerning one's own cognitive processes and products or anything related to them, e.g. the learning related properties of information and data". He further describes metacognition as "the active monitoring and consequent regulation and orchestration of these processes in relation to the cognitive objects or data on which they bear, usually in the service of some concrete goal or objective" (Flavell, 1976). There is a growing theoretical and practical interest in the topic of metacognition: how we monitor and control our own mental processes (Pintrich, 1999). Metacognition has made contributions to two applied domains, namely education, specially applications towards improving learning and training and legal contexts (Schwartz \& Perfect, 2002). An important aspect of learning is using Cognitive and Metacognitive strategies to control and regulate students' own learning.

Metacognition is a construct similar to Executive Decision Making Process of Information Processing System. Metacognition is also an aspect of Self-regulation. One of the schools of thought that has contributed to enhance the knowledge in the construct of Self-regulated Learning is 'Metacognition and Regulation Styles'(Boekaerts, 1999). Many research studies on Self-regulated Learning play a major role in understanding classroom learning processes and facilitating the intellectual development of the child, (Newman, 1990; Zimmerman, \& Bandura, 1994; Schunk, \& Zimmerman, 1994; Boekaerts, \& Minnaert, 1999) centered on cognitive and metacognitive strategies such as mnemonic encoding and self-monitoring (Zimmerman, \& Bandura, 1994). According to the constructivist viewpoint, the learner should have a control over his or her own learning because the responsibility is with him in sensitizing with the learning and the student needs cognitive and metacognitive knowledge and skills to do this successfully.

Although, as a new construct, the concept of Selfregulated Learning is embraced by policy makers, teachers, educationists and parents (Boekaerts, 1999), the research emphasis in Sri Lanka on the concept of 
metacognition is not grounded and its application at classroom level is yet to be identified.

Metacognitive skills and strategies can be used in any subject area of school curriculum and in the thought processes of children such as attention, motivation, learning, memory, and understanding (Linn, 1986; Nickerson, 1986; Carrol, 1986).

Further, there are 'General metacognitive skills and strategies' that can be applied across different subject areas or mental processes and 'Specific metacognitive skills and strategies' that can be used in specific subject areas or mental processes. The present study focuses on a specific subject area, i.e. writing of secondary school children, which according to Scardamalia \& Bereiter (1986a) has gained academic attention recently, although it had been neglected until now.

Four aspects of writing have been focused on in research literature on Writing and the present study focuses on the aspect of 'incidents and processes occurred in the mind during Writing in the classroom setting.

\section{LITERATURE SURVEY}

\section{Metacognition}

Based on the theoretical explanations (Flavell, 1976; Brown, \& Smiley, 1977; Flavell, 1979; Brown, 1980; ; Cavanaugh, \& Perlmutter, 1982; Meichenbaum, Burland, Gruson, \& Cameron, 1985; Wellman, 1985; Beyer, 1987; Brown, 1987; White, 1988) two aspects of metacognition are delineated for the study. They are,

- Knowledge and awareness about cognitive behaviour/ processes and,

- Monitoring and controlling of such knowledge and awareness to regulate cognitive behaviour/ processes.

Learning strategies that display Knowledge, Awareness, Monitoring and Controlling have been identified by researchers in different subject areas and mental processes. According to Paris, Saarnio, \& Cross (1986), the strategies are skimming, rereading, paraphrasing, and summarizing. Ellis (1986) cited planning, checking, testing, revising and evaluation as strategies. Baird (1986) cites confirmation of the topic, evaluation of knowledge, reviewing the structure of the message, extracting important sections, and evaluating outcome of learning as learning strategies. Moely, Hart, Santulli, Leal, Johnson, Rao, \& Burney (1986) named rehearsal, chunking, categorization, verbal elaboration, and note taking as general strategies. Weinstein, \& Mayer (1986) categorize strategies into eight as basic rehearsal strategies, complex rehearsal strategies, basic elaboration strategies, complex elaboration strategies, basic organizational strategies, complex organizational strategies, comprehension monitoring strategies, and affective and motivational strategies.

In Sri Lanka, Gorrell, Dharmadasa, Kularatne, \& Abeyratne (1996) found that older children in primary classes tend to use more complex strategies and younger children tend to use basic learning strategies. Use of strategies by children also differed according to the subjects being studied. Further, Sri Lankan primary school children function effectively and strategically in their classroom performances. Gorrell, Dharmadasa, \& Dharmadasa (1999) studied learning strategies of self evaluation, organization and transformation, goal setting, planning, seeking information, self monitoring, adjusting environment, rehearsing, memorizing, seeking peer help, and seeking help from parents and teachers, used in problem solving.

Use of specific strategies in the writing behaviour is focused on in the present study. Hence metacognition is defined, for the purpose of this study as the knowledge, awareness and monitoring and the controlling of that knowledge and awareness, in using strategies for writing.

The present research focuses on the Writing Strategies, and 'knowledge and awareness' of children on the Writing Strategies and the 'monitoring, controlling, and regulating of such 'knowledge and awareness' in the three stages of the Writing Process: Planning, Writing and Revising.

\section{Writing Process}

Writing is a complex activity (Archibald, \& Jeffery, 2000). It also has a recursive process. The present trend of research into the writing of children focuses on the process of writing rather than on the product of writing, and on the recursive nature of writing rather than the linear nature of writing (Rohman, 1965; Britton, Burgess, Martin, Mcleod, \& Rosen, 1975; Hayes, \& Flower, 1980; Flower, \& Hays, 1981a; Graves, 1983; Murray, 1984; Bereiter, \& Scardamalia, 1987; Moore, \& Caldwell, 1993; Hayes, \& Nash, 1996; Torrance, Thomas, \& Robinson, 1999; Torrance, Thomas, \& Robinson, 2000).

Although Planning, Composing and Revising stages are 
overlapping in the Writing Process, they can be taken separately to facilitate description (Hartley, 1994).

An important time log of Writing should be focused on Planning Stage of Writing where the goal setting occurs (Murray, 1978; Flower, \& Hays, 1980a; Moffett, 1982; Graves, 1983; Rohman, 1983). Goal setting is one important aspect of good writing (Page-Voth, \& Graham, 1999).

During the second stage of Writing Process, i.e. the Writing Stage, ideas are translated into the written mode. The writer is expected to perform many tasks during this period and due to this, writing becomes an unusually complex task (Biggs, Lai, Tang, \& Lavelle, 1999).

Revising which enhances the quality of an essay is a basic and important aspect of the Writing process (Murray, 1978; Scardemalia, \& Bereiter, 1986a; Fitzgerald, 1987; Fitzgerald, \& Markman, 1987; Graham, MacArthur, \& Schwartz, 1995). Professional writers set apart considerable time for Revising (Hildick, 1965; Graham, MacArthur, \& Schwartz, 1995).

Effective Revising results in good Writing (Murray, 1978; Bridwell, 1980). Many writers, however, revise little (National Assessment of Educational Progress, 1977; Scardamalia, 1981; Bartlett, 1982; Hull, 1987; Englert, Hiebert, \& Stewart, 1988). They tend to be proof readers rather than reviewers whose role is to edit the document to suit a known audience (Sommers, 1980; Faigley \& Witte, 1981).

In American Public Schools many children do not revise competently and effectively (Fitsgerald, \& Markman, 1987; Fitzgerald, 1987; Graham, MacArthur, \& Schwartz, 1995). They focus on mechanical and word-level changes (Bridwell, 1980; Faigley, \& Witte, 1981; Scardamalia, \& Bereiter, 1986a; Scardamalia, \& Bereiter, 1986b; Graham, MacArthur, \& Schwartz, 1995) and their Revising influences a little on the quality of Writing (Bracewell, Scardamalia, \& Bereiter,
1978; Scardamalia, \& Bereiter, 1986a; Scardamalia, \& Bereiter, 1986b; Graham, MacArthur, \& Schwartz, 1995). Their sense of audience is limited, resulting in less Revision (MacArthur, Schwartz, \& Graham, 1991; Graham, MacArthur, \& Schwartz, 1995). In Sri Lanka, a study on Metacognitive Writing is yet to be completed.

\section{OBJECTIVES}

The objectives of the research were to identify metacognitive strategies used by secondary school children (Grades 6-10) in the three stages of Writing Process, to identify distribution patterns of metacognitive strategies used by secondary school children within 'metacognitive strands (Awareness and Regulation)' and 'metacognitive fields (Generating ideas, Goal setting, Organization, Self monitoring and Self evaluation)'; to identify the nature of their knowledge/ awareness and monitoring / regulation of metacognitive strategies and to identify whether the metacognitive strategies used differ according to the type of school (rural / urban), grade (6-10) and sex (boy / girl). Figure 1 shows the conceptual model of the study.

\section{METHODOLOGY}

The sample comprised 725 children (Male $=363$; Female $=362$ ) of Grade $6,7,8,9$, and 10 from four purposively selected schools (Urban $=2$; Rural $=2)$. A sub sample of 120 children was used to collect 408 observation notes and written exercises as classroom artifacts. They were collected from 278 Mother Tongue lessons by 12 data collectors, including the researcher. Two hundred and eighty nine interviews were conducted with the children focusing on their writing behaviour (Table 1).

Based on the data collected from the sub sample of 120 children, a questionnaire was developed to collect data from the sample of 725 students.

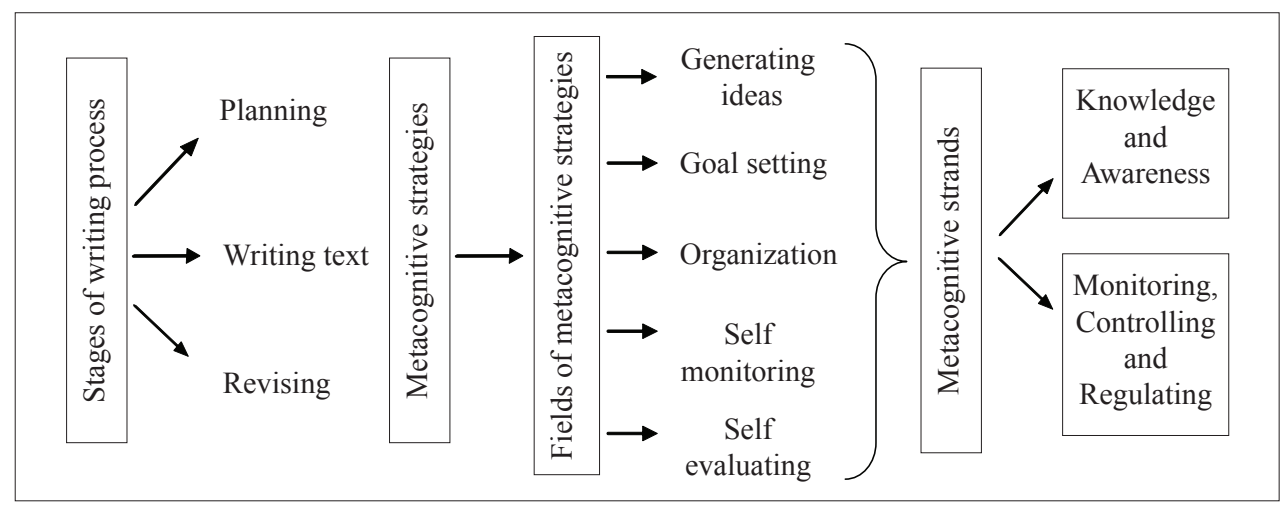

Figure 1. Conceptual model of the study 
Table 1: Mother Tongue lessons (Interviews and Observations)

\begin{tabular}{|c|c|c|c|c|c|c|c|c|c|c|c|c|}
\hline \multirow[t]{2}{*}{ School } & \multicolumn{6}{|c|}{ No. of observed lessons } & \multicolumn{6}{|c|}{ No. of interviews } \\
\hline & 6 & 7 & 8 & 9 & 10 & Total & 6 & 7 & 8 & 9 & 10 & Total \\
\hline A & 16 & 19 & 20 & 16 & 17 & 88 & 22 & 19 & 30 & 22 & 16 & 109 \\
\hline B & 22 & 17 & 16 & 11 & 21 & 87 & 15 & 13 & 15 & 20 & 19 & 82 \\
\hline $\mathrm{C}$ & 9 & 12 & 9 & 9 & 11 & 50 & 12 & 12 & 8 & 6 & 6 & 44 \\
\hline $\mathrm{D}$ & 10 & 10 & 10 & 13 & 10 & 53 & 12 & 11 & 8 & 19 & 4 & 54 \\
\hline Total & 57 & 58 & 55 & 49 & 59 & 278 & 61 & 55 & 61 & 67 & 45 & 289 \\
\hline
\end{tabular}

Observation and interview data, qualitative in nature, collected from 120 children were transcribed, coded and frequencies were calculated according to the Stages of writing (Planning, Writing, Revising), Metacognitive strategy fields (Generating ideas, Goal setting, Organization, Self monitoring and Self evaluation), Metacognitive strands (Awareness and Regulation) and 72 Metacognitive strategies. Differences between proportions of frequencies were tested using $\mathrm{z}$ test. In the reporting of findings, extracts of classroom artifacts, observations and interviews were quoted as qualitative examples.

The quantitative data derived from the questionnaire, that were used to study the generalizability of patterns identified from 120 students, were analyzed using 'Hierarchical tree cluster analysis' to identify speculative patterns, 'Chi square test' to identify confirmed patterns and 'Factor analysis' to identify specific patterns.

\section{Delimitations and Limitations}

The study focused on writing activities performed as a part of curriculum implementation in the selected grades. Specifically designed writing activities by the researcher were not used since the objective was to identify metacognitive strategies in writing in the natural classroom setting. A secondary grade, Grade 11 was not included due to its exam oriented writing behaviour.

Only 604 children responded to the questionnaire, due to the involvement of the other children in pre assigned school activities (Table 2).

Table 2: Student responses to questionnaire

\begin{tabular}{|c|c|c|c|c|c|c|}
\hline \multirow{2}{*}{$\begin{array}{c}\text { Environment } \\
\text { of school }\end{array}$} & \multirow{2}{*}{$\begin{array}{c}\text { Sex } \\
\text { of the child }\end{array}$} & \multicolumn{5}{|c|}{ Grades } \\
\hline & & 6 & 7 & 8 & 9 & 10 \\
\hline \multirow[t]{2}{*}{ Rural } & Boys & 35 & 38 & 38 & 29 & 32 \\
\hline & Girls & 26 & 33 & 32 & 30 & 27 \\
\hline \multirow[t]{2}{*}{ Urban } & Boys & 36 & 53 & 24 & 41 & 24 \\
\hline & Girls & 16 & 23 & 20 & 28 & 19 \\
\hline \multirow[t]{2}{*}{ Total } & Boys & 71 & 91 & 62 & 70 & 56 \\
\hline & Girls & 42 & 56 & 52 & 58 & 46 \\
\hline \multicolumn{2}{|c|}{ Total } & 113 & 147 & 114 & 128 & 102 \\
\hline \multicolumn{2}{|c|}{ Grand Total } & \multicolumn{5}{|c|}{604} \\
\hline
\end{tabular}




\section{Ethical Considerations}

The consent of school principals and teachers was obtained for the research on the assurance that classroom and school activities would not be affected.

\section{DATA PRESENTATION AND DISCUSSION}

\section{Patterns Emerging from sub sample}

\subsection{Time taken for each stage of writing process: the content analysis}

It could be identified that there were two sub periods in Mother tongue lessons, the time taken by the teacher to teach and the time taken by the student to write. The average percentage of time in which, 120 children of the sub sample engaged in the writing during their observed 278 Mother Tongue lessons was 60\%
(Rural 67\%, Urban 54\%). Gradewise percentages were 58\% (Grade 6), 58\% (Grade 7), 67\% (Grade 8), 62\% (Grade 9), and 56\% (Grade 10) (Table 3).

During the observation of Writing activities by 12 observers, children entered into the Writing stage of the Writing process in 408 instances. Out of the 408 instances, Planning stage of the Writing process was observed in $19 \%$ of the instances (Rural 17\%, Urban 21\%) and Revising in $12 \%$ of the instances (Rural 5\%, Urban 21\%). The main reason for the less time period for Revision was the limited 40 minute time period for lessons. During the Writing stage, however, children engaged in Planning in $65 \%$ of the instances (Rural 62\%, Urban 67\%) and in Revising in $75 \%$ of the instances (Rural 68\%, Urban $82 \%$ ). Hence, Writing stage was dominant in the Writing Process of male and female students in both urban and rural schools and in Grades 6-10 students. Rather than being in two separate stages, Planning and Revision were mixed in the Writing stage, because children tended to plan and revise while Writing.

Table 3: Relative time spent on each stage of writing

\begin{tabular}{|c|c|c|c|c|c|c|c|c|c|c|c|c|}
\hline \multirow{3}{*}{$\begin{array}{l}\text { Grade } \\
\text { School }\end{array}$} & \multicolumn{2}{|c|}{6} & \multicolumn{2}{|c|}{7} & \multicolumn{2}{|c|}{8} & \multicolumn{2}{|c|}{9} & \multicolumn{2}{|c|}{10} & \multirow{2}{*}{\multicolumn{2}{|c|}{ Grand total }} \\
\hline & \multicolumn{10}{|c|}{ Time } & & \\
\hline & $\begin{array}{l}\text { Lessons: } \\
\text { Minutes }\end{array}$ & $\begin{array}{l}\text { Writing: } \\
\text { Minutes }\end{array}$ & $\begin{array}{l}\text { Lessons: } \\
\text { Minutes }\end{array}$ & $\begin{array}{l}\text { Writing: } \\
\text { Minutes }\end{array}$ & $\begin{array}{l}\text { Lessons: } \\
\text { Minutes }\end{array}$ & $\begin{array}{l}\text { Writing: } \\
\text { Minutes }\end{array}$ & $\begin{array}{l}\text { Lessons: } \\
\text { Minutes }\end{array}$ & $\begin{array}{l}\text { Writing: } \\
\text { Minutes }\end{array}$ & $\begin{array}{l}\text { Lessons: } \\
\text { Minutes }\end{array}$ & $\begin{array}{l}\text { Writing: } \\
\text { Minutes }\end{array}$ & $\begin{array}{l}\text { Lessons: } \\
\text { Minutes }\end{array}$ & $\begin{array}{l}\text { Writing: } \\
\text { Minutes }\end{array}$ \\
\hline $\begin{array}{l}\text { Sch. A } \\
\text { Sch. B }\end{array}$ & $\begin{array}{l}537 \\
652\end{array}$ & $\begin{array}{l}334 \\
456\end{array}$ & $\begin{array}{l}659 \\
880\end{array}$ & $\begin{array}{l}352 \\
472\end{array}$ & $\begin{array}{l}684 \\
941\end{array}$ & $\begin{array}{l}404 \\
798\end{array}$ & $\begin{array}{l}491 \\
627\end{array}$ & $\begin{array}{l}424 \\
449\end{array}$ & $\begin{array}{l}584 \\
543\end{array}$ & $\begin{array}{l}373 \\
379\end{array}$ & $\begin{array}{l}2955 \\
3643\end{array}$ & $\begin{array}{l}1887 \\
2554\end{array}$ \\
\hline $\begin{array}{l}\text { Rural } \\
\text { Total }\end{array}$ & 1189 & $\begin{array}{l}790 \\
66 \% \\
\end{array}$ & 1539 & $\begin{array}{l}824 \\
54 \% \\
\end{array}$ & 1625 & $\begin{array}{l}1202 \\
74 \% \\
\end{array}$ & 1118 & $\begin{array}{l}873 \\
78 \% \\
\end{array}$ & 1127 & $\begin{array}{l}752 \\
67 \% \\
\end{array}$ & 6598 & $\begin{array}{l}4441 \\
67 \% \\
\end{array}$ \\
\hline Sch. C & 640 & 346 & 770 & 545 & 827 & 597 & 547 & 292 & 725 & 297 & 3509 & 2077 \\
\hline Sch. D & 727 & 344 & 867 & 460 & 851 & 418 & 1032 & 499 & 704 & 378 & 4181 & 2099 \\
\hline $\begin{array}{c}\text { Urban } \\
\text { Total }\end{array}$ & 1367 & $\begin{array}{r}690 \\
50 \% \\
\end{array}$ & 1637 & $\begin{array}{l}1005 \\
61 \% \\
\end{array}$ & 1678 & $\begin{array}{l}1015 \\
60 \% \\
\end{array}$ & 1579 & $\begin{array}{r}791 \\
50 \% \\
\end{array}$ & 1429 & $\begin{array}{r}675 \\
47 \% \\
\end{array}$ & 7690 & $\begin{array}{l}4176 \\
54 \% \\
\end{array}$ \\
\hline Total & 2556 & 1480 & 3176 & 1829 & 3303 & 2217 & 2697 & 1664 & 2556 & 1427 & 14288 & 8617 \\
\hline $\begin{array}{l}\text { Grand } \\
\text { Total }\end{array}$ & & $\underline{58 \%}$ & & $\underline{58 \%}$ & & $\underline{67 \%}$ & & $\underline{62 \%}$ & & $\underline{56 \%}$ & & $\underline{60 \%}$ \\
\hline
\end{tabular}




\subsection{Metacognitive strategies used in each stage of the Writing Process: Observation data}

When the notes taken during the lesson observations were translated into graphs (Fig. $2 \& 3$ ) to accentuate patterns, the relative expansion of stages of writing could be further identified. In the graphs, the process of writing of children were depicted through signs which are cited below the Fig. 2 as a key. In some places of the graphs, to highlight the stages of writing process, words have been written using English phonetic scripts. As an example in the Fig. 2 Sinhala word 'vivida' (English meaning = various) is written as 'vivida'.

According to the patterns in the graphs, children did not spend time for Planning and right away started writing. During the explanation of lessons by teachers, only three children 'took notes independently' by way of writing the meaning of difficult words, showing the metacognitive regulation behaviour. During the explaining of lessons, however, mental metacognitive strategies of 'identifying the necessity for writing', 'knowledge on the specific task and task difficulty', 'using prior knowledge' and 'identifying the goal of writing' were emerging in the minds of the children. Children tend to begin writing at once as the teacher wants them to start writing, based on this basic conceptual springboard. Major parts of graphs are dominated by the Writing Stage of the Writing Process indicating the importance children place on the Writing Stage. Hence a Writing Stage dominated Writing Process could be identified. As revision is not a separate section of the Writing Process, it mixes with the Writing Stage. Accordingly, children revised while writing the text, not after finishing the text. Hence, a recursive process of writing could be identified. Further, their revisions were limited to mechanical revisions i.e. Writing on the letters to have them clearer, preparation of vowel sounds, colouring letters to make them prominent and making surface level changes of the text i.e. Striking off written words, writing new words, writing correct letters / words for incorrect ones.

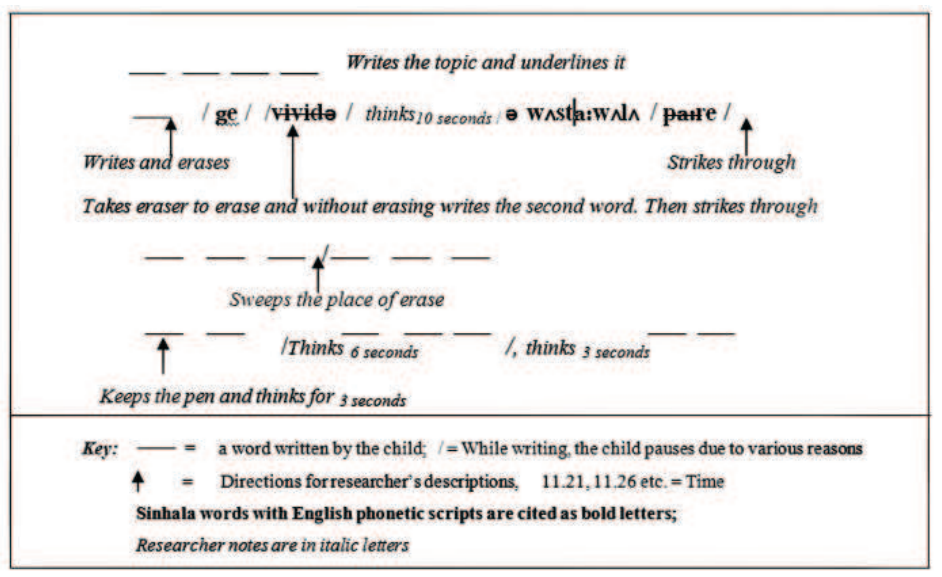

Figure 2: Graph showing the flow of writing of child A65F

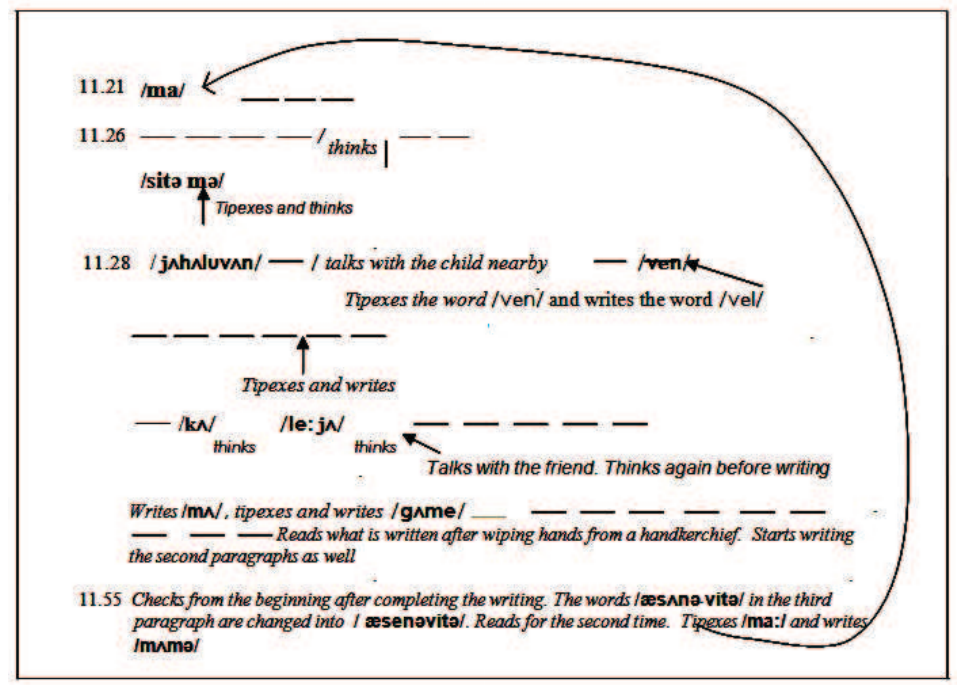

Figure 3: Graph showing the flow of writing of child A66F 


\subsection{Metacognitive strategies used in each stage of the Writing Process: Analysis of qualitative data}

The writing stage which dominated the writing process could also be identified from the extracts of interview data.

\subsubsection{The Planning of Writing}

The Planning of Writing is mainly a mental process that could not be visible through external behaviours, i.e. preparation of drafts, taking notes. Only four children out of 120 used drafts for writing during the observations. The ideas expressed in interviews by children (I thought a little, I thought about this piece of writing and then wrote, memorized what the teachers had taught us and wrote, I recollected facts) show the mental Planning for Writing.

Children do not show awareness or regulation of metacognitive strategies in the Writing process (Fig 4 \& 5). The obvious metacognitive strategy that was not used in Planning was 'Goal setting' (Fig 6 \& 7). Out of the 40 metacognitive strategies related to Planning of Writing: 'memorizing relevant facts', 'using prior knowledge', 'reading to collect information', 'seeking information', were used by the children.

\begin{tabular}{|c|c|}
\hline Researcher & $\begin{array}{l}\text { You did not write anything during } \\
\text { the teacher's explanation. Did you? }\end{array}$ \\
\hline Student & Yes \\
\hline Researcher & $\begin{array}{l}\text { Why didn't you write while the } \\
\text { teacher was explaining? }\end{array}$ \\
\hline Student & We do not do it other days also \\
\hline Researcher & $\begin{array}{l}\text { So, you just listen. Don't you? Can } \\
\text { you remember all the facts teacher } \\
\text { explains? Don't you forget? }\end{array}$ \\
\hline Student & I forget some facts. \\
\hline Researcher & Then why don't you take notes? \\
\hline Student & No Answer \\
\hline
\end{tabular}

Figure 4: An extract from an interview with the child B105F

\begin{tabular}{|c|c|}
\hline Researcher & $\begin{array}{l}\text { Did you have a plan at the } \\
\text { beginning of the writing? }\end{array}$ \\
\hline Student & Yes, first we have to introduce. \\
\hline Researcher & Then \\
\hline Student & No answer \\
\hline Researcher & $\begin{array}{l}\text { When you started writing did you } \\
\text { have an idea about the length and } \\
\text { the content of the essay? }\end{array}$ \\
\hline Student & $\begin{array}{l}\text { No such thing. I kept important } \\
\text { facts in my memory. }\end{array}$ \\
\hline
\end{tabular}

Figure 5: An extract from an interview with the child

\begin{tabular}{|lll|}
\hline Researcher & $:$ & $\begin{array}{l}\text { Did you decide that you were going } \\
\text { to write this much of facts? }\end{array}$ \\
Student & $:$ & No \\
Researcher & $:$ & Did you think of writing a little? \\
Student & $:$ & No \\
Researcher & $:$ & Then why did you write a little? \\
Student & $:$ & While I was writing I had no idea \\
& $\begin{array}{l}\text { about my piece of writing. While } \\
\text { writing I thought this much would } \\
\text { be enough. }\end{array}$ \\
&
\end{tabular}

Figure 6: An extract from an interview with the child A65F

\begin{tabular}{|c|c|c|}
\hline Researcher & & $\begin{array}{l}\text { Did you write this dialogue using } \\
\text { your memory? }\end{array}$ \\
\hline Student & : & $\begin{array}{l}\text { No, I just wrote the ideas that came } \\
\text { into mind at that time. }\end{array}$ \\
\hline Researcher & : & $\begin{array}{l}\text { Didn't you write what the book } \\
\text { mentioned? }\end{array}$ \\
\hline Student & : & $\begin{array}{l}\text { I took one episode and wrote one } \\
\text { conversation and then thought } \\
\text { about the next conversation } \\
\text { later. I thought about the beginning } \\
\text { but not about the end of the } \\
\text { dialogue. }\end{array}$ \\
\hline Researcher & & $\begin{array}{l}\text { Do you have the whole story in } \\
\text { your mind? }\end{array}$ \\
\hline Student & & $\begin{array}{l}\text { No. I take one incident and expand } \\
\text { it. I write one and then think about } \\
\text { the next thing to be written. After } \\
\text { writing one word, think about the }\end{array}$ \\
\hline
\end{tabular}

Figure 7: An extract from an interview with the child B102M

Analysis of interview data in relation to five matacognitive fields reveals the fact that the field of goal setting was weak during the Planning Stage.

\subsubsection{The Writing Stage}

Absence of Planning Stage, results in a Writing Stage where children tend to write what they have in their minds at the moment of writing. The unawareness of the writing task in the Writing Stage also surfaced (Fig 8).

\begin{tabular}{|lll}
\hline Researcher & $:$ & The teacher asked you to write \\
& LIYO. But you have written Lio. \\
& Why? \\
Student & $:$ & Madam, I forgot it. I was not aware
\end{tabular}

Figure 8: An extract from an interview with the child B83M 
Children entered the Writing Stage with 'awareness on the present cognitive status' and they had the awareness of the 'ongoing writing activity'. 'While writing they thought about the writing' and 'took decisions on paragraphing and organizing the written work'. Due to this metacognitive awareness during the Writing Stage, they could identify the places where revisions were necessary and edit the written work accordingly (Fig. 9).

$\begin{array}{ll}\text { Researcher } & : \text { You wrote the words "Parakrama } \\ & \text { Samudraya" and thought for a } \\ & \text { while. Why? } \\ \text { Student } & : \text { I thought whether it was right. } \\ \text { Researcher } & : \text { Why did you cut a word in the } \\ & \text { fourth line of the third paragraph? } \\ \text { Student } & : \text { I thought about a better word }\end{array}$

Figure 9: An extract from an interview with the child B95F

Although metacognitive regulation strategies of 'transformation of content of the piece of writing to produce a better product', 'thinking about the writing task and as a result self monitoring', and 'reflecting on the writing task' could be found in some of the children who were in the Writing Stage of the Writing Process, as a whole, there exists a 'knowledge telling behaviour' rather than a 'knowledge transformation behaviour' proving the theory of writing suggested by Scardamalia \& Bereiter (1986ab) (Fig 10, 11 \& 12).

\begin{tabular}{|ll|}
\hline Researcher & $: \begin{array}{l}\text { How did you think about writing in } \\
\text { this way? }\end{array}$ \\
Student & $: \begin{array}{l}\text { While I was writing facts it came } \\
\text { into my mind. Hence I wrote in that } \\
\text { way. }\end{array}$ \\
Researcher $\quad:$ & $\begin{array}{l}\text { That means you do not think about } \\
\text { the things you are going to write at } \\
\text { the beginning, at the middle of the } \\
\text { essay and at the end of the essay? } \\
\text { Student }\end{array}$ \\
& Yes
\end{tabular}

Figure 10: An extract from an interview with the child C66F

\begin{tabular}{|ll|}
\hline Researcher & $:$ I saw you striking off a word here \\
Student & $:$ First of all I began to write this \\
& sentence. Afterwards this word \\
& came into my mind. Hence I wrote \\
& that word.
\end{tabular}

Figure 11: An extract from an interview with the child D95F

$$
\begin{array}{ll}
\text { Researcher } & : \text { That means you think before you } \\
& \text { write? } \\
\text { Student } & : \text { I keep on writing and if the facts } \\
& \text { do not come into my mind I stop } \\
& \text { writing. }
\end{array}
$$

Figure 12: An extract from an interview with the child B103M

When the interview data were analysed according to five matacognitive fields, the field of generating ideas seemed to overlap with the Writing Stage.

\subsubsection{The Revision Stage}

Twelve percent of the children who entered the Revision Stage of Writing Process as well as others who revised the writing, while they were still at the Writing Stage tended to make mechanical changes and surface level changes. There was no metacognitive awareness of deep level revising.

It was observed that the fields of self evaluation and organization were mixing with the Revision Stage, when the interview data were analysed according to five metacognitive fields,

As a whole the self regulation field could not be found in the writing behaviour of secondary school children.

\subsection{Metacognitive emphasis on each stage of the Writing Process: Quantitative analysis of interview data}

The fact that the Writing Stage dominated the Writing Process could also be identified from the quantified interview data. 2481 steps of 289 interviews were read, coded and analyzed quantitatively to identify the distribution of student ideas in the three stages of the Writing Process, the five fields of metacognition and the 72 metacognitive strategies.

Of the total number of times mentioned (3715), Writing Stage was mentioned in $49 \%$, as against $31 \%$ on the Planning Stage and $20 \%$ on the Revising Stage. The emphasis on Writing Stage as against the other two stages and on Planning Stage against Revision Stage was significant at 0.5 (Table 4). Hence, the dominance of the Writing Stage could be discerned in the Writing Process. 
Table 4: Distribution and significance of expressed ideas of students according to stages of writing

\begin{tabular}{|c|c|c|}
\hline Stages of writing & $\begin{array}{c}\text { Number of times } \\
\text { mentioned }\end{array}$ & $\%$ \\
\hline Planning & 1153 & $31 \%$ \\
\hline Writing & 1814 & $49 \%$ \\
\hline Revising & 748 & $20 \%$ \\
\hline Total & $\mathbf{3 7 1 5}$ & $\mathbf{1 0 0} \%$ \\
\hline
\end{tabular}

\begin{tabular}{|c|c|c|c|}
\hline \multirow{2}{*}{$\begin{array}{c}\text { Comparison of variables } \\
\text { (proportionate } \mathrm{Z} \text { test) }\end{array}$} & Planning $<>$ Writing & Planning $<>$ Revising & Writing < > Revising \\
\cline { 2 - 4 } & 1.0000 & 0.0000 & 0.0000 \\
\hline P value & Sig $<$ & Sig $>$ & Sig $>$ \\
\cline { 2 - 4 } & &
\end{tabular}

When the data were analyzed according to variables of sex, environment of the school (Rural/Urban) and grade $(6,7,8,9,10)$, emphasis on the Writing Stage could be identified (Tables 5, $6 \& 7$ ). However, girls emphasize the Planning Stage whereas boys emphasize the Writing Stage and urban students emphasize the Planning Stage and rural students emphasize the Writing Stage. Grade 6 students emphasize Planning and Writing Stages significantly and Grade 8 and 9 students emphasize Writing Stage as against Planning significantly. Further, Grade 8 students emphasize Planning than Revision.

Table 5: Distribution and significance of expressed ideas of students according to stages of writing and sex of the student

\begin{tabular}{|c|c|c|c|c|}
\hline Stages of writing & Boys & \% & Girls & \% \\
\hline Planning & 452 & $28 \%$ & 701 & $33 \%$ \\
\hline Writing & 831 & $51 \%$ & 983 & $47 \%$ \\
\hline Revising & 335 & $21 \%$ & 413 & $20 \%$ \\
\hline Total & $\mathbf{1 6 1 8}$ & $\mathbf{1 0 0 \%}$ & $\mathbf{2 0 9 7}$ & $\mathbf{1 0 0 \%}$ \\
\hline
\end{tabular}

\begin{tabular}{|l|c|c|c|c|}
\hline \multirow{2}{*}{ Comparison of variables } & \multicolumn{3}{|c|}{ Stages of writing } \\
\cline { 2 - 4 } & Planning & Writing & Revising \\
\hline \multirow{2}{*}{ P value } & \multirow{2}{*}{ Boys $<>$ Girls } & 0.9999 & 0.0033 & 0.2239 \\
\cline { 2 - 4 } & & Sig $<$ & Sig $>$ & Not Sig \\
\hline
\end{tabular}

Table 6: Distribution and significance of expressed ideas of students according to stages of writing and environment of the school

\begin{tabular}{|c|c|c|c|c|c|c|}
\hline Stages of writing & Rural & $\mathbf{\%}$ & Urban & $\mathbf{\%}$ & Total & $\%$ \\
\hline Planning & 568 & $28 \%$ & 585 & $35 \%$ & 1153 & $100 \%$ \\
\hline Writing & 1034 & $51 \%$ & 780 & $46 \%$ & 1814 & $100 \%$ \\
\hline Revising & 427 & $21 \%$ & 321 & $19 \%$ & 748 & $100 \%$ \\
\hline Total & $\mathbf{2 0 2 9}$ & $\mathbf{1 0 0} \%$ & $\mathbf{1 6 8 6}$ & $\mathbf{1 0 0} \%$ & $\mathbf{3 7 1 5}$ & $\mathbf{1 0 0} \%$ \\
\hline
\end{tabular}

\begin{tabular}{|c|c|c|c|c|}
\hline \multicolumn{2}{|c|}{$\begin{array}{c}\text { Comparison of } \\
\text { variable }\end{array}$} & Planning & Writing & Revising \\
\cline { 2 - 4 } & Boys $<>$ Girls & 1.0000 & 0.0021 & 0.0638 \\
\cline { 3 - 5 } P value & Sig $<$ & Sig $>$ & Not Sig \\
\hline
\end{tabular}


Table 7: Ideas expressed by students according to stages of writing and grades

\begin{tabular}{|c|c|c|c|c|c|c|c|c|c|c|}
\hline Grade & \multicolumn{2}{|c|}{$\mathbf{6}$} & \multicolumn{2}{|c|}{$\mathbf{7}$} & \multicolumn{2}{c|}{$\mathbf{8}$} & \multicolumn{2}{c|}{$\mathbf{9}$} \\
\hline $\begin{array}{c}\text { Stages of } \\
\text { writing }\end{array}$ & Total & $\mathbf{\%}$ & Total & $\mathbf{\%}$ & Total & $\%$ & Total & $\%$ & Total & \% \\
\hline Planning & 178 & 29 & 246 & 31 & 158 & 26 & 258 & 28 & 313 & 40 \\
\hline Writing & 285 & 46 & 372 & 47 & 337 & 55 & 478 & 53 & 342 & 44 \\
\hline Revising & 155 & 25 & 169 & 22 & 120 & 19 & 176 & 19 & 128 & 16 \\
\hline Total & $\mathbf{6 1 8}$ & $\mathbf{1 0 0}$ & $\mathbf{7 8 7}$ & $\mathbf{1 0 0}$ & $\mathbf{6 1 5}$ & $\mathbf{1 0 0}$ & $\mathbf{9 1 2}$ & $\mathbf{1 0 0}$ & $\mathbf{7 8 3}$ & $\mathbf{1 0 0}$ \\
\hline
\end{tabular}

\begin{tabular}{|c|c|c|c|}
\hline \multirow{2}{*}{$\begin{array}{c}\text { Comparison of variable } \\
\text { (Grades) }\end{array}$} & Planning & Writing & Revising \\
\hline & P-Value & P-Value & P-Value \\
\hline \multirow[t]{2}{*}{$6<>7$} & 0.26046 & 0.3909 & 0.84829 \\
\hline & Not Sig & Not Sig & Not Sig \\
\hline \multirow[t]{2}{*}{$6<>8$} & 0.79356 & 0.02098 & 0.94274 \\
\hline & Not Sig & Sig $>$ & Not Sig \\
\hline \multirow[t]{2}{*}{$6<>9$} & 0.52149 & 0.27535 & 0.75452 \\
\hline & Not Sig & Not Sig & Not Sig \\
\hline \multirow[t]{2}{*}{$6<>10$} & 0.04322 & 0.64238 & 0.95568 \\
\hline & Sig $>$ & Not Sig & Sig $<$ \\
\hline \multirow[t]{2}{*}{$7<>8$} & 0.91239 & 0.04902 & 0.70296 \\
\hline & Not Sig & Sig $>$ & Not Sig \\
\hline \multirow[t]{2}{*}{$7<>9$} & 0.62085 & 0.31484 & 0.60147 \\
\hline & Not Sig & Not Sig & Not Sig \\
\hline \multirow[t]{2}{*}{$7<>10$} & 0.09662 & 0.69942 & 0.83625 \\
\hline & Not Sig & Not Sig & Not Sig \\
\hline \multirow[t]{2}{*}{$8<>9$} & 0.39372 & 0.58808 & 0.51008 \\
\hline & Not Sig & Not Sig & Not Sig \\
\hline \multirow[t]{2}{*}{$8<>10$} & 0.01632 & 0.94557 & 0.72663 \\
\hline & Sig $>$ & Not Sig & Not Sig \\
\hline \multirow[t]{2}{*}{$9<>10$} & 0.14394 & 0.76884 & 0.62511 \\
\hline & Not Sig & Not Sig & Not Sig \\
\hline
\end{tabular}

When the data were compared among grades $(6,7$, $8,9,10)$ Grade 6 children significantly emphasized more on Revision than Grade 10 children and
Grade 10 children significantly emphasized more on Planning than Grade 6 children (Table 8).

Table 8: Expressed ideas of students according to fields of metacognition

\begin{tabular}{|c|c|c|}
\hline Metacognitive fields & No. of times expressed & \% \\
\hline Generating ideas & 1386 & $26 \%$ \\
\hline Goal setting & 441 & $8 \%$ \\
\hline Organizing & 1183 & $22 \%$ \\
\hline Monitoring & 1301 & $24 \%$ \\
\hline Evaluating & 1058 & $20 \%$ \\
\hline Total & $\mathbf{5 3 6 9}$ & $\mathbf{1 0 0} \%$ \\
\hline
\end{tabular}




\begin{tabular}{|c|c|}
\hline Comparison of variables & p-value \\
\hline \multirow[t]{2}{*}{1 Generating ideas $<>2$ Goal setting } & 1.0000 \\
\hline & Sig $<$ \\
\hline \multirow[t]{2}{*}{1 Generating ideas $<>3$ Organizing } & 0.8349 \\
\hline & Not Sig \\
\hline \multirow[t]{2}{*}{1 Generating ideas $<>4$ Monitoring } & 0.6292 \\
\hline & Not Sig \\
\hline \multirow[t]{2}{*}{1 Generating ideas $<>5$ Evaluating } & 0.8214 \\
\hline & Not Sig \\
\hline \multirow[t]{2}{*}{2 Goal setting $<>3$ Organizing } & 0.0000 \\
\hline & Sig $>$ \\
\hline \multirow[t]{2}{*}{2 Goal setting $<>4$ Monitoring } & 0.0002 \\
\hline & Sig $>$ \\
\hline \multirow[t]{2}{*}{2 Goal setting $<>5$ Evaluating } & 0.0364 \\
\hline & Sig $>$ \\
\hline \multirow[t]{2}{*}{3 Organizing $<>4$ Monitoring } & 0.3314 \\
\hline & Not Sig \\
\hline \multirow[t]{2}{*}{3 Organizing $<>5$ Evaluating } & 0.6338 \\
\hline & Not sig \\
\hline \multirow[t]{2}{*}{4 Organizing $<>5$ Evaluating } & 0.7303 \\
\hline & Not Sig \\
\hline
\end{tabular}

\subsection{Emphasis on each Metacognitive Field: Quantified interview data}

Out of the Metacognitive Fields, Generating Ideas, Organization, Monitoring and Evaluation were mentioned $26 \%, 22 \%, 24 \%$, and $20 \%$ respectively of the total terms (5369) as against $8 \%$ on Goal Setting. The less emphasis on Goal Setting is significant (Table 8). Significantly less emphasis on Goal Setting was established when data was analyzed according to variables of sex and environment of the school. According to grades, however, there was no significant difference between metacognitive fields. Girls set goals before writing than boys and boys tended to organize writing during the Writing Stage.

The Writing Style of telling ideas during the Writing Stage, gained from the teacher during the period of explaining the lesson could be visible. Since the Goal Setting was not prominent, children use knowledge telling strategies rather than knowledge transforming strategies in their writing.

\subsection{Emphasis on each Metacognitive Strategy: Quantitative analysis of interview data}

Out of the 72 metacognitive strategies in writing considered in the study, 40 were related to Planning Stage, 19 were related to the Writing Stage and 13 to Revision Stage. The metacognitive strategies related to Writing Stage were cited as being used in $48 \%$ of instances, Planning Stage in 30\% instances and Revision Stage only in $22 \%$ instances. The data indicate the emphasis on the Writing Stage than the other two stages. When the 72 metacognitive strategies were ranked according to the emphasis in interviews (Table 9), ranking first was the 'regulating thinking on the Writing Process while writing'. The reason for this may be that the writing behaviour of Planning and Revision falls within the Writing Stage itself. The least emphasized metacognitive strategy was 'summarizing and paraphrasing' indicating the minor emphasis on Revision within the Writing Process. The most emphasized strategy was 'regulating thinking on the Writing Process' and the least emphasized strategy was 'summarizing and paraphrasing'. Tendency of children to focus more on the Writing Stage and less on Revision is amply demonstrated by these relative emphases too.

Seventy-two metacognitive strategies were classified into nine categories, based on their ranks and the most emphasized metacognitive strategies and least emphasized metacognitive strategies were identified. 
Out of the most emphasized metacognitive strategies five were related to Planning Stage and three were related to Writing Stage. None of the strategies were related to Revision. Strategies related to Planning were linked with the mental processes of children that help them to gain information from the lesson taught by the teacher using their memory and readiness of the child for learning. The metacognitive strategy, 'checking the effectiveness of the approached solution' ranked ninth was the first metacognitive strategy related to Revision that was found in the list and until 27th rank, no other strategy related to Revision would be found in the ranking list showing less emphasis on Revision strategies.

Table 9: Ranks of specific metocognitive strategies according to the ideas of students

\begin{tabular}{|c|c|c|c|c|}
\hline $\begin{array}{l}\text { No. of the } \\
\text { strategy }\end{array}$ & $\begin{array}{l}\text { No. of times } \\
\text { expressed }\end{array}$ & Rank & $\begin{array}{l}\text { Stage of } \\
\text { writing }\end{array}$ & Strategy \\
\hline 45 & 688 & 1 & Writing & Thinking of the writing process \\
\hline 48 & 584 & 2 & Writing & $\begin{array}{l}\text { Showing awareness on present cognitive and emotional status } \\
\text { when using cognitive processes related to writing }\end{array}$ \\
\hline 5 & 521 & 3 & Planning & Being aware of the task assigned \\
\hline 18 & 480 & 4 & Planning & Memorizing \\
\hline 1 & 470 & 5 & Planning & Self evaluation \\
\hline 2 & 436 & 6 & Planning & Understanding the necessity of writing \\
\hline 22 & 426 & 7 & Planning & Seeking information \\
\hline 51 & 426 & 8 & Writing & Self monitoring of progress \\
\hline 62 & 426 & 9 & $\underline{\text { Revising }}$ & Checking the effectiveness of the approached solution \\
\hline 46 & 342 & 10 & Writing & Using writing effectively \\
\hline 50 & 337 & 11 & Writing & $\begin{array}{l}\text { Using a monitoring plan to assess the effectiveness of writing } \\
\text { task }\end{array}$ \\
\hline 56 & 334 & 12 & Writing & Checking again while engaged in the writing \\
\hline 49 & 295 & 13 & Writing & Reflecting on the writing task \\
\hline 19 & 259 & 14 & Planning & Adjusting facts mentally \\
\hline 53 & 248 & 15 & Writing & $\begin{array}{l}\text { Making changes for a better document while engaged in writ- } \\
\text { ing }\end{array}$ \\
\hline 3 & 247 & 16 & Planning & Evaluating the necessity for writing \\
\hline 37 & 241 & 17 & Planning & Identifying solution strategies as hints \\
\hline 4 & 232 & 18 & Planning & $\begin{array}{l}\text { Knowledge on the specific writing task, its difficulties and skills } \\
\text { needed for it }\end{array}$ \\
\hline 52 & 229 & 19 & Writing & Depend on surface level characteristics \\
\hline 15 & 203 & 20 & Planning & Knowing when, where, how, and what is to be written \\
\hline 27 & 198 & 21 & Planning & Selection of suitable information \\
\hline 47 & 198 & 22 & Writing & Using the writing format effectively \\
\hline 6 & 197 & 23 & Planning & Predicting problems \\
\hline 14 & 189 & 24 & Planning & Changing strategies according to task \\
\hline 44 & 187 & 25 & Writing & Using facts and instructions learned previously \\
\hline 41 & 184 & 26 & Writing & Transformation of writing \\
\hline 61 & 182 & 27 & $\underline{\text { Revising }}$ & Awareness on the necessity on revision \\
\hline 20 & 178 & 28 & Planning & Using prior knowledge \\
\hline 57 & 178 & 29 & Writing & Sensitivity to external communicators and environment \\
\hline 63 & 177 & 30 & $\underline{\text { Revising }}$ & Making mechanical changes to produce better document \\
\hline 35 & 164 & 31 & Planning & Considering alternative strategies \\
\hline 21 & 160 & 32 & Planning & $\begin{array}{l}\text { Using brainstorming, reading, interviewing, observing to ac- } \\
\text { quire information }\end{array}$ \\
\hline
\end{tabular}




\begin{tabular}{|c|c|c|c|c|}
\hline $\begin{array}{l}\text { No. of the } \\
\text { strategy }\end{array}$ & $\begin{array}{l}\text { No. of times } \\
\text { expressed }\end{array}$ & Rank & $\begin{array}{l}\text { Stage of } \\
\text { writing }\end{array}$ & Strategy \\
\hline 43 & 155 & 33 & Writing & Awareness on the facts and grammar needed for writing \\
\hline 8 & 152 & 34 & Planning & $\begin{array}{l}\text { Identifying the goal } \\
\text { Identifying the necessity for developing a specific plan }\end{array}$ \\
\hline 11 & 140 & 35 & Planning & When encountered a task to be implemented without other's help \\
\hline 25 & 140 & 36 & Planning & Depicting thinking via physical acts \\
\hline 10 & 139 & 37 & Planning & Metacognitive task of predicting on the effectiveness of writing \\
\hline 64 & 135 & 38 & Revising & Making surface level changes to produce better document \\
\hline 9 & 126 & 39 & Planning & Setting manageable goals \\
\hline 72 & 126 & 40 & $\underline{\text { Revising }}$ & $\begin{array}{l}\text { Identifying qualities and weaknesses of own writing due to the } \\
\text { intervention of an external person }\end{array}$ \\
\hline 23 & 125 & 41 & Planning & Seeking help from peers/teachers/ adults \\
\hline 67 & 115 & 42 & $\underline{\text { Revising }}$ & Evaluating the quality of writing \\
\hline 13 & 104 & 43 & Planning & Changing strategies according to writing task assigned \\
\hline 55 & 103 & 44 & Writing & Considering contingency plans when facing a problem \\
\hline 59 & 93 & 45 & Writing & Forward planning while doing the task \\
\hline 54 & 92 & 46 & Writing & Organization of facts \\
\hline 33 & 87 & 47 & Planning & Using necessary information to solve problems \\
\hline 36 & 85 & 48 & Planning & Choosing a strategy among many \\
\hline 39 & 85 & 49 & Planning & Rehearsal \\
\hline 7 & 81 & 50 & Planning & Thinking of the audience \\
\hline 38 & 74 & 51 & Planning & Systematic planning \\
\hline 66 & 71 & 52 & $\underline{\text { Revising }}$ & Reviewing notes \\
\hline 42 & 66 & 53 & Writing & Regulating pre-planning to suit the finishing of the writing task \\
\hline 30 & 63 & 54 & Planning & Separation of basic facts \\
\hline 65 & 59 & 55 & $\underline{\text { Revising }}$ & Deep level revising to produce a better writing \\
\hline 12 & 51 & 56 & Planning & Preparation of drafts \\
\hline 40 & 45 & 57 & Planning & Adjusting environment \\
\hline 69 & 45 & 58 & $\underline{\text { Revising }}$ & Taking action to collect extra information \\
\hline 70 & 43 & 59 & $\underline{\text { Revising }}$ & Recasting the expected meaning \\
\hline 34 & 40 & 60 & Planning & Identifying alternative concepts \\
\hline 26 & 39 & 61 & Planning & Keeping records / notes \\
\hline 29 & 34 & 62 & Planning & Dividing into parts \\
\hline 68 & 33 & 63 & $\underline{\text { Revising }}$ & Predicting new incidents \\
\hline 32 & 32 & 64 & Planning & Categorization of basic facts \\
\hline 24 & 30 & 65 & Planning & Regulating thinking using more than two media \\
\hline 58 & 28 & 66 & Writing & Adjusting beginning, middle and end of the writing while writing \\
\hline 71 & 28 & 67 & $\underline{\text { Revising }}$ & Looking at own writing as a reader \\
\hline 17 & 22 & 68 & Planning & Self instructional \\
\hline 16 & 18 & 69 & Planning & Mnemonic encoding \\
\hline 28 & 18 & 70 & Planning & Writing again as facts \\
\hline 60 & 17 & 71 & $\underline{\text { Revising }}$ & Summarizing/ paraphrasing \\
\hline 31 & 16 & 72 & Planning & Summarizing basis facts \\
\hline
\end{tabular}


The emphasis placed on product of Writing has to be changed to an emphasis on process of writing at the classroom level teaching learning process. The Planning Stage was dominated by teacher explanations and providing facts about the lesson. This period can be used to enlighten the Metacognitive strategies of children. However children do memorize as a strategy during the lesson explaining stage. Memorization is the fourth in rank out of the 72 metacognitive strategies (Table 9).

\section{Patterns Emerging from the Sample of $\mathbf{7 2 5}$ Students}

The responses for the 113 items developed to represent metacognitive strategies in the Writing process in the structured questionnaire were analyzed in three stages to see whether the findings of the sub sample could be generalized to the selected classrooms with 725 children.

\subsection{Hierarchical Tree Cluster Analysis}

The speculative patterns that emerged from Hierarchical Tree Cluster analysis showed a similarity in metacognitive strategies used by boys and girls in rural and urban schools. There emerged a distant relationship in metacognitive use between Grade 6 children and children in Grades 7, 8, 9 \& 10 (Fig. 13, 14, \&15).

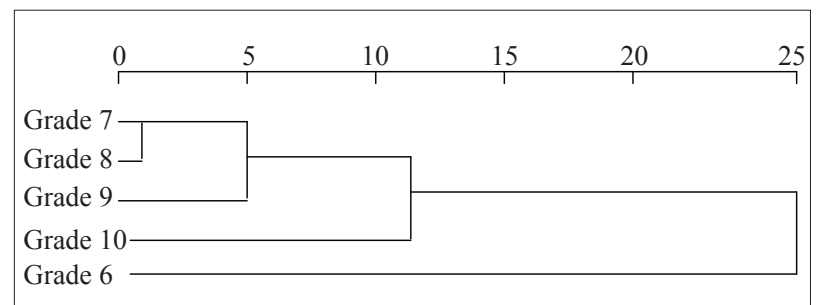

Figure13: Clustering of responses of students according to grade

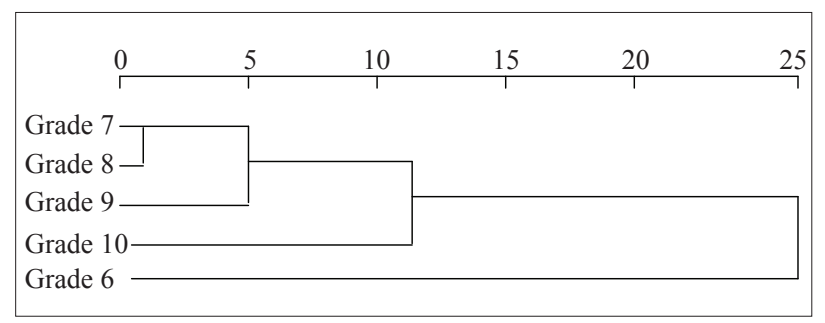

Figure 14: Clustering of responses of boys according to grade

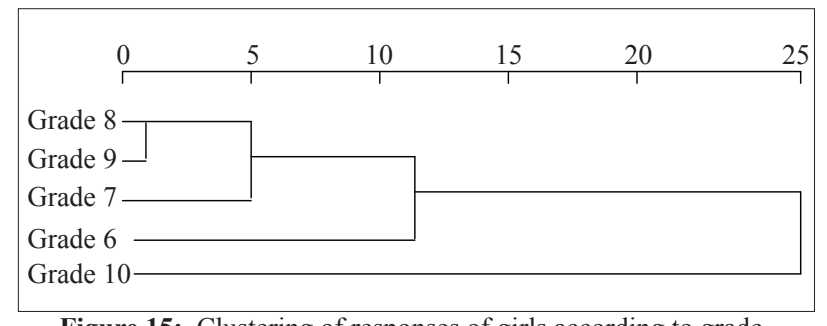

Figure 15: Clustering of responses of girls according to grade

\subsection{Chi Square Test}

Chi square test on 113 items that represented metacognitive strategies in writing of the questionnaire confirmed the distanced pattern between the Planning / Revision Stages and the Writing Stage. Also the test confirmed the mixture of Planning and Revision behaviour with the Writing Stage i.e. children's behaviour of Planning and Revising while they were writing.

Seventy three percent of the items of the questionnaire did not significantly relate to the variable of school and $70 \%$ of the items of the questionnaire did not significantly relate to the school grades. However, only $46 \%$ of the items of the questionnaire did not significantly relate to the variable of sex. Hence it seems that although there is no division between schools and grades, there is a tendency towards girl - boy dichotomy.

The 30 items out of 113 of the questionnaire that were not significantly related to school, grade and sex of the child were categorized into three stages of Writing Process (Table 10) to identify common metacognitive strategies for all children in the sample and their distribution in the stages of the writing process. Accordingly seven items related to Planning indicates the 'engagement in mental pre-writing' with less cognitive effort. Also the 'using of drafts to organize ideas effectively' and other complex Planning strategies are weak in the writing behaviour of the children. As a result when writing, children 'first write one sentence and then think about one by one about the other sentences' rather than using prior planning during the Planning Stage to write effectively during the Writing Stage.

Twelve items related to Writing Stage showed the difficulties children were facing due to lack of planning and external factors that influenced the writing task. 'The difficulty in writing the first sentence', 'forgetting of words while writing' were the difficulties faced due to poor pre- planning. 'Hindrance or disturbances of friends', 'looking at writing of others' were the external factors that influenced writing. However children could 'add extra facts to the appropriate places while they were writing' and 'concentrate on letters omitted'. Hence they are in a position to regulate their writing at the Writing Stage.

Seven items related to Revision indicate the awareness about the revision behavior during the Writing Stage. The revision made during the Writing Stage, however, was limited to mechanical and surface level changes. They were not aware about the deep level revising. They were also not aware of the need for revision after the Writing Stage as they were 'content with the written work' and their speculation on their own writing was 'a success'. 
Table 10: Distribution of items in the questionnaire which are not significantly related to school, grade and sex according to stages of writing

\begin{tabular}{|c|c|c|c|}
\hline $\begin{array}{l}\text { No. of } \\
\text { item }\end{array}$ & Strategy & Stage of writing & $\begin{array}{l}\text { Strategy or } \\
\text { metacognitive } \\
\text { strand }\end{array}$ \\
\hline 21 & I feel it is difficult to write the first sentence & Writing & Awareness \\
\hline 23 & $\begin{array}{l}\text { Even after writing the first sentence, I have to remind the other sentences } \\
\text { one by one }\end{array}$ & Writing & Strategy \\
\hline 27 & Sometimes I find it difficult to understand what to write & Planning & Awareness \\
\hline 30 & Sometimes I feel that I do not understand how to write & Planning & Awareness \\
\hline 32 & $\begin{array}{l}\text { I know the reasons for not understanding how to write an assigned writing } \\
\text { task }\end{array}$ & Planning & Awareness \\
\hline 42 & It is my habit to imagine and write the whole sentence & Planning & Strategy \\
\hline 21 & I feel it is difficult to write the first sentence & Writing & Awareness \\
\hline 23 & $\begin{array}{l}\text { Even after writing the first sentence, I have to remind the other sentences } \\
\text { one by one }\end{array}$ & Writing & Strategies \\
\hline 36 & $\begin{array}{l}\text { I forgot what to write, when my friends trouble me after starting the } \\
\text { writing task }\end{array}$ & Writing & Regulation \\
\hline 39 & $\begin{array}{l}\text { If someone is observing while I am writing, I can not do it well and I make } \\
\text { many mistakes }\end{array}$ & Writing & Regulation \\
\hline 43 & $\begin{array}{l}\text { The facts that come to my mind after writing something are added to } \\
\text { necessary places later }\end{array}$ & Writing/Revising & Strategies \\
\hline 45 & I forget the words while I am writing & Writing & Awareness \\
\hline 48 & $\begin{array}{l}\text { I am unable to write the difficult words found in the copy writing looking } \\
\text { only once at them }\end{array}$ & Writing & Regulation \\
\hline 49 & As I forget some letters in words I have to write them with much concern & Writing & Regulation \\
\hline 50 & I do not know why I write some words incorrectly & Writing & Awareness \\
\hline 82 & $\begin{array}{l}\text { When writing essays, it is my habit to think about all the facts at first and } \\
\text { then to continue writing }\end{array}$ & Planning (Essay) & Strategies \\
\hline 91 & I need to complete writing an essay assigned to me as soon as possible & Writing (Essay) & Strategies \\
\hline 93 & $\begin{array}{l}\text { It is somewhat difficult for me to decide what to include in an essay. But it } \\
\text { is easy for me to answer the questions in the text book. }\end{array}$ & Planning (Essay) & Regulation \\
\hline 98 & When writing an essay, first I imagine it; then start writing & Planning (Essay) & Strategies \\
\hline 99 & I relate my experiences to the essay & Writing (Essay) & Strategies \\
\hline 103 & I make corrections in essays, if the teacher asks only & Revising (Essay) & Regulation \\
\hline 60 & It is my habit to highlight unclear letters by writing again on them & Revising & Strategies \\
\hline 68 & I handover my writing to the teacher if I feel I have written them well & Writing & Awareness \\
\hline 80 & I can speculate how successful my piece of writing is & Writing & Awareness \\
\hline 70 & $\begin{array}{l}\text { I hand over product of writing to the teacher whether it was written in a } \\
\text { good way or not because I can finish the writing within the period }\end{array}$ & $\begin{array}{l}\text { Controlling writing } \\
\text { due to external } \\
\text { factors: Revising }\end{array}$ & Regulation \\
\hline 75 & $\begin{array}{l}\text { I hand over product of writing to the teacher whether it was written in a } \\
\text { good way or not because I can't show the writing next day to the teacher } \\
\text { to be corrected }\end{array}$ & $\begin{array}{l}\text { Controlling writing } \\
\text { due to external } \\
\text { factors: Revising }\end{array}$ & Regulation \\
\hline 77 & $\begin{array}{l}\text { I hand over product of writing to the teacher whether it was written in a } \\
\text { good way or not because I am praised by the teacher when I finish the } \\
\text { writing task earlier }\end{array}$ & $\begin{array}{l}\text { Controlling writing } \\
\text { due to external } \\
\text { factors: Revising }\end{array}$ & Regulation \\
\hline 78 & $\begin{array}{l}\text { I hand over product of writing to the teacher whether it was written } \\
\text { in a good way or not because Due to competition with other } \\
\text { children I want to show the teacher first }\end{array}$ & $\begin{array}{l}\text { Controlling writing } \\
\text { due to external } \\
\text { factors: Revising }\end{array}$ & Regulation \\
\hline
\end{tabular}




\subsection{Factor Analysis}

The specific patterns identified through factor analysis confirm the patterns that emerged so far. The 31 items of the questionnaire that were significantly related to school, 34 items significantly related to grade and 61 items significantly related to sex of the child were categorized into 11,11 , and 4 factors respectively and they were compared with the three stages of Writing Process, metacognitive strands and specific metacognitive strategies (Table 11, 12 \& 13).

Table 11: Factors according to school

\begin{tabular}{|c|}
\hline $\begin{array}{l}\text { Factor } 1 \\
\text { Without the stage of Revising. Negative awareness on the writing } \\
\text { strategies (Related items of questionnaire } 14,24,57,58,72,89 \text { ) }\end{array}$ \\
\hline $\begin{array}{c}\text { Factor } 2 \\
\text { Can not identify the Planning Stage specifically. Planning } \\
\text { characteristics can be seen within the Writing strategies (Related } \\
\text { items of questionnaire } 3,4,5,6,83 \text { ) }\end{array}$ \\
\hline $\begin{array}{c}\text { Factor } 3 \\
\text { There is awareness and strategies on Planning. Regulate such } \\
\text { strategies during the Writing Stage (Related items of questionnaire } \\
97,100,105)\end{array}$ \\
\hline \begin{tabular}{|c|} 
Factor 4 \\
Awareness on writing mixed with visible Planning strategies (Related \\
items of questionnaire $8,9,107)$
\end{tabular} \\
\hline $\begin{array}{c}\text { Factor } 5 \\
\text { Control writing by environmental factors (Related items of } \\
\text { questionnaire } 26,37)\end{array}$ \\
\hline $\begin{array}{c}\text { Factor } 6 \\
\text { Ability and non ability to regulate Writing according to } \\
\text { awareness and strategies about Planning (Related items of } \\
\text { questionnaire } 11,12,86)\end{array}$ \\
\hline $\begin{array}{c}\text { Factor } 7 \\
\text { Sculptural Writing and Revising. No Planning (Related items of } \\
\text { questionnaire } 1,111)\end{array}$ \\
\hline $\begin{array}{c}\text { Factor } 8 \\
\text { Can evaluate the Writing if there is awareness and strategies about } \\
\text { mental Planning (Related items of questionnaire } 7,13,79)\end{array}$ \\
\hline $\begin{array}{c}\text { Factor } 9 \\
\text { Using awareness on Planning to revise Writing (Related items of } \\
\text { questionnaire } 10,61)\end{array}$ \\
\hline $\begin{array}{c}\text { Factor } 10 \\
\text { Regulation of Writing (Related items of questionnaire } 64,71 \text { ) }\end{array}$ \\
\hline $\begin{array}{l}\text { Factor } 11 \\
\text { Effective Writing without Planning (Related items of questionnaire } \\
20)\end{array}$ \\
\hline
\end{tabular}

Out of the 11 factors related to school, the first, second and third factors do not include metacognitive strategies related to Planning and Revision. Although awareness and strategies were included in the third factor, visible
Planning was shown only in the fourth factor. Regulation of Planning was not included in any of the factors and Revision was shown only in the seventh factor. Hence according to the factor analysis on school, a Writing Style dominated by Writing and less emphasized by Planning and Revision could be identified. Although children have specific writing strategies, their awareness and regulation of such strategies have less importance (Table 11).

Grade wise analysis also shows less importance being given to the Planning Stage and more importance given to the Writing and Revising Stages in the first four factors. In the 5th factor, Planning is seen but with a mixture of Writing and Revising, emphasizing its lower independence. Although Writing and Revising is visible in the first factor, awareness and regulation of strategies are prominent, and they are controlled by external factors and internal factors of the student.

Table 12: Factors according to Grades

\begin{tabular}{|c|}
\hline Factor 1 \\
$\begin{array}{c}\text { No Planning. Awareness, strategies and regulating on Writing and } \\
\text { Revision controlled by external factors and internal factors of the } \\
\text { child (Related items of questionnaire. 34, 56, 108, 113) }\end{array}$ \\
$\begin{array}{c}\text { Factor } 2 \\
\text { Regulation of awareness and strategies on Writing. No regulation of } \\
\text { Revision (Related items of questionnaire 24, 57, 11, 74, 41, 95) }\end{array}$ \\
\hline $\begin{array}{c}\text { Factor } 3 \\
\text { Strong awareness on Writing (Related items of questionnaire 73, 51, } \\
88 \text { ) }\end{array}$ \\
$\begin{array}{c}\text { Factor } 4 \\
\text { Writing without Planning. Sculptural Writing. However, no Revision } \\
\text { (Related items of questionnaire 5, 6) }\end{array}$ \\
\hline \hline Factor 5
\end{tabular}

Awareness, strategies and regulation on Planning and Revision (Related items of questionnaire 85, 59, 65, 106)

\begin{tabular}{|c|}
\hline \\
\hline $\begin{array}{c}\text { Factor } 7 \\
\text { Regulation of strategies mixed with Planning and Writing (Related } \\
\text { items of questionnaire } 29,44,97)\end{array}$ \\
\hline $\begin{array}{c}\text { Factor } 8 \\
\text { Awareness on Writing (Related items of questionnaire 55, }\end{array}$ \\
\hline $\begin{array}{c}\text { Factor } 9 \\
\text { Awareness on Knowledge Telling Writing strategies without Plannin } \\
\text { (Related items of questionnaire 104, 101) }\end{array}$ \\
\hline $\begin{array}{c}\text { Factor } 10 \\
\text { Revising based on awareness on Writing (Related items of } \\
\text { questionnaire } 66,15)\end{array}$ \\
\hline $\begin{array}{l}\text { Factor 11 } \\
\text { Regulating Writing strategies, sensitizing Revision and controlling } \\
\text { effects of external environment (Related items of questionnaire } 90 \\
38,76)\end{array}$ \\
\hline
\end{tabular}


Sculptural Writing Style could be identified due to the Planning free writing (Table 12).

Even the sex wise analysis shows less importance being given to Planning (Table 13).

Table 13: Factors according to sex of students

\begin{tabular}{|c|}
\hline Factor 1 \\
$\begin{array}{c}\text { Writing without Planning. Awareness on the difficulty of Writing. } \\
\text { Writing behaviour according to external variables. No goal setting } \\
\text { and self regulation. (Related items of questionnaire 14, 24, 57, 58, } \\
72,89 \text { ) }\end{array}$ \\
\hline $\begin{array}{c}\text { Factor } 2 \\
\text { No Planning. Writing according to teacher instructions and texts and } \\
\text { experiences (Related items of questionnaire 101, 11) }\end{array}$ \\
\hline $\begin{array}{c}\text { Factor } 3 \\
\text { No regulating of time. There is self awareness (Related items of } \\
\text { questionnaire 92,90) }\end{array}$ \\
Writing according to teacher instructions and memory (Related item \\
of questionnaire 12)
\end{tabular}

\section{CONCLUSIONS}

The Planning Stage of children is dominated by explanation of the lesson by the teacher, which gives children ideas that can be used in the Writing Stage. The metacognitive strategies used in the Planning Stage are 'awareness about the assigned writing task', 'memorizing', 'self-evaluation', 'understanding the necessity for writing', 'seeking information', 'adjusting facts in mind', and 'evaluating the need for writing'. The lesser used strategies in the Planning stage are 'summarizing basic facts', 'rewriting as facts', 'mnemonic', 'self instructional coding', 'thinking using more than two media', 'classification of basic facts, 'breaking into parts', 'keeping reports / notes', 'identification of alternative concepts', and 'adjusting the environment'. Metacognitive field of 'Goal setting' is not used for Planning. Students do not show an awareness or regulation of metacognitive strategies in metacognitive strands on Planning.

The metacognitive strategies used in the Writing Stage are 'self-regulation of Writing', 'activating cognitive processes about Writing,, 'showing awareness on present cognitive and emotional status in the Writing Process' and 'self-monitoring of progress'. Least used metacognitive strategy is 'adjusting the beginning, middle and end aspects of the Writing activity while facing external influences'.

A mechanical and surface level Revising Style can be identified among students. Deep level changes are not found. The only metacognitive strategy used in Revising Stage is 'checking the product of Writing'. Least used metacognitive strategies for Revising are 'summarizing/ paraphrasing', 'seeing his/ her own written work as a reader', 'predicting new incidents', 'recreating expected meaning' and 'taking necessary steps to add extra information'.

'Knowledge Telling Process' rather than 'Knowledge Transformation Process' can be found in the Writing Process of secondary school children proving the theory of writing suggested by Scardamalia and Bereiter.

Metacognitive strategies used by students, their awareness of those and the way they regulated metacognitive strategies do not differ according to rural schools and urban schools. Writing characteristics of Grade 6 children are distanced from Grade 7, 8, 9, and 10. There is no significant difference between girls and boys on ideas of Revising Stage. However there is a tendency towards a boy - girl dichotomy with regard to using metacognitive strategies in the Writing Process. Girls emphasize the Planning Stage than boys and boys emphasize the Writing Stage than girls.

A hunch, which needs further research to be confirmed, can be found about the sculpture style of writing of grade 6 children as against the Engineering style of writing of grade 10 children.

\section{SUGGESTIONS}

Due to the lack of emphasis on Planning and Revising in the Writing Process at classroom level, it is necessary to enhance the quality of written work / writing assignments of students. Therefore:

- There is a need for training on metacognitive strategies for students;

- Methods of training on metacognitive strategies should be included in teacher training courses;

- Methods of training on metacognitive strategies should be included in teacher guides and textbooks.

- The emphasis placed on product of Writing has to be changed to an emphasis on the process of writing at the classroom level teaching-learning process. 


\section{ACKNOWLEDGEMENTS}

Dr. W.A.R. Wijeratne \& Dr. N.G. Kularatne of the Faculty of Education, Open University of Sri Lanka for the academic guidance on Doctor of Philosophy Thesis on "Metacognitive strategies used by Secondary school children in the writing process"

Academic staff members of the Faculty of Education, Open University of Sri Lanka and National Science Foundation for the research grant (RG/2001/SIDA/ $\mathrm{SS} / 04)$.

\section{References}

1. Archibald, A. \& Jeffery, G.C., 2000. Second language acquisition and writing: A multidisciplinary approach. Learning and Instruction, 10 (1), pp. 1-11.

2. Baird, J.R., 1986. Improving learning through enhanced metacognition: A classroom study. European Journal of Science Education, 8, pp. 263282.

3. Bartlett, E.J., 1982. Learning to revise: Some component processes. In: M. Nystrand, ed. What writers know. San Diego, CA: Academic press, pp. 345-365.

4. Bereiter, C.\& Scardamalia, M., 1987. The psychology of written composition. Hillsdale, NJ: Erlbaum.

5. Beyer, B., 1987. Practical strategies for the teaching of thinking. Boston: Allyn \& Bacon.

6. Biggs, J., Lai, P., Tang, C. \& Lavelle, E., 1999. Teaching writing to ESL graduate students: A model and an illustration. British Journal of Educational Psychology, 69 (3), pp. 293-306.

7. Boekaerts, M., 1999. Self-regulated learning: Where we are today. International Journal of Educational Research, 31, pp. 445-457.

8. Boekaerts, M. \& Minnaert, A., 1999. Self- regulation with respect to informal learning. International Journal of Educational Research, 31, pp. 533- 544.

9. Bracewell, R.J., Scardamalia, M. \& Bereiter, C., 1978. The development of audience awareness in writing. ERIC Document Reproduction Service No ED 154433.
10. Bridwell, L.S.,1980. Revising strategies in twelfth grade students' transactional writing. Research in the Teaching of English, 14, pp. 197-222.

11. Britton, J. et al., 1975. The development of writing abilities. London: Macmillan Education, pp. 11-18.

12. Brown, A.L., 1980. Metacognitive development and reading. In R.J. Spiro, B.C. Bruce, \& W.F. Brewer. eds., Theoretical issues in reading comprehension: Perspectives from cognitive psychology, linguistics, artificial intelligence, and education. Hillsdale, New Jersey: Erlbaum.

13. Brown, A.L., 1987. Metacognition, executive control, self-regulation, and other more mysterious mechanisms. In F. Weinert, \& R. Kluwe. eds., Metacognition, motivation, and understanding. Hillsdale, New Jersey: Erlbaum, pp. 65-116.

14. Brown, A.L. \& Smiley, S.S., 1977. Rating the importance of structural units of prose passages: A problem of metacognitive development. Child Development, 48, pp.1-8.

15. Carrol, J.B., 1986. Second language. In R.F. Dillon, \& R.J. Sternberg. eds., Cognition and instruction. Orlando: Academic press, pp. 83-125.

16. Cavanaugh, J.C. \& Perlmutter, M., 1982. Metamemory: A critical examination. Child Development, 53, pp. 11-28.

17. Ellis, E.S., 1986. The role of motivation and pedagogy on the generalization of cognitive strategy training. Journal of Learning Disability, 19, pp. 6670.

18. Englert, C.S. Hiebert, E.H. \& Stewart, S.R., 1988. Detecting and correcting inconsistencies in the monitoring of expository prose. Journal of Educational Research, 81, pp. 221-227.

19. Faigley, L. \& Witte, S., 1981. Analyzing revision. College Composition and Communication, 32, pp. 400-414.

20. Fitzgerald, J., 1987. Research on revision in writing. Review of Educational Research, 57 (4), pp. 481506.

21. Fitzgerald, J. \& Markman, L., 1987. Teaching children about revision in writing. Cognition and 
Instruction, 4, pp. 3-24.

22. Flavell, J.H., 1976. Metacognitive aspects of problem solving. In: L.B. Resnick, ed. The nature of intelligence. Hillsdale, New Jersey: Lawrencc Erlbaum, pp. 231-235.

23. Flavell, J.H., 1979. Metacognition and cognitive monitoring: A new area of cognitive developmental inquiry. American Psychologist, 34 (10), pp. 906911.

24. Flower, L.S. \& Hays, J.R., 1980. The dynamics of composing: Making plans and juggling constraints. In: L.W. Gregg \& E.R. Steinberg. eds. Cognitive processes in writing. Hillsdale, NJ: Lawrence Erlbaum, pp. 31-50.

25. Flower, L.S. \& Hays, J.R., 1981. A cognitive process theory of writing. College Composition and Communication, 32 (4), pp. 365-387.

26. Gorrell, J. J., Dharmadasa, K.H., Kularatne, N.G. \& Abeyratne, L.A., 1996. Understanding Sri Lankan child: An observational study of primary school children's use of learning strategies in the classroom. SAARC Journal of Educational Research, 2(1), pp. 1-20.

27. Gorrell, J. J., Dharmadasa, K. H., \& Dharmadasa, I., 1999. Understanding the Sri Lankan child: Phase three-Self regulation and problem solving: Children's responses to a self - regulated behaviour interview. Report submitted to the National Institute of Education, Sri Lanka (Unpublished).

28. Graham, S., MacArthur, C. \& Schwartz, S., 1995. Effects of goal setting and procedural facilitation on the revising behaviour and writing performance of students with writing and learning problems. Journal of Educational Psychology, 87(2), pp. 230-240.

29. Graves, D.H., 1983. Writing: Teachers and children at work. New York: Heinneman Educational.

30. Hartley, J., 1994. Designing instructional text. 3rd ed. London: Kogan Page.

31. Hayes, J.R. \& Flower, L.S., 1980. Identifying the organization of writing processes. In: L.W. Gregg \& E.R. Steinberg, eds. Cognitive processes in writing. Hillsdale, New Jersey: Erlbaum, pp. 3-30.
32. Hayes, J.R. \& Nash, J.G., 1996. A new model of cognition and affect in writing. In: C.M. Levy \& S. Ransdell, eds. The science of writing: Theories, methods, individual differences and applications. Mahwah, NJ: Erlbaum, pp. 29-56.

33. Hildick, E., 1965. Word for word: The rewriting of fiction. London: Farber and Farber.

34. Hull, G., 1987. The editing process in writing: A performance study of more skilled and less skilled college writers. Research in the Teaching of English, 21, pp. 8-29.

35. Linn, M.C., 1986. Science. In: R.F. Dillon, \& R.J. Sternberg, eds. Cognition and Instruction. Orlando: Academic press, pp. 155-204.

36. MacArthur, C.A., Schwartz, S. \& Graham, S., 1991. Effects of a reciprocal peer revision strategy in special education classrooms. Learning Disabilities Research and Practice, 6, pp. 201-210.

37. Meichenbaum, D.H., Burland, S., Gruson, L. \& Cameron, R., 1985. Metacognitive assessment. In: S.R. Yussen, ed. The growth of reflection in children. New York: Academic Press.

38. Moely, B. et al., 1986. How do teachers teach memory skills? Educational Psychologist, 21, pp. $55-7$.

39. Moffett, J., 1982. Writing, inner speech and meditation. College of English, 44 (3), pp. 231-264.

40. Moore, B.H. \& Caldwell, H., 1993. Drama and drawing for narrative writing in primary grades. Journal of Educational Research, 87(2), pp. 100110.

41. Murray, D.M., 1978. Writing before writing. ERIC Document Reproduction Service No. ed. pp. 157194.

42. Murray, D.M., 1984. Write to learn. New York: Holt, Rinehart \& Winston.

43. National Assessment of Educational Progress, 1977. Write / rewrite : An assessment of revision skills: Selected results from the Second National Assessment of writing (Writing report No. 05 - W 04). Washington, DC: National Institute of Education. 
44. Newman, R.S., 1990. Children's help seeking in the classroom: The role of motivational factors and attitudes. Journal of Educational Psychology, 82 (1), pp. $71-80$.

45. Nickerson, R.S., 1986. Reasoning. In: R.F. Dillon \& R.J. Sternberg, eds. Cognition and instruction. Orlando: Academic press, pp. 343-373.

46. Page-Voth, V. \& Graham, S., 1999. Effects of goal setting and strategy use on the writing performance and self efficacy of students with writing and learning problems. Journal of Educational Psychology, 92(2), pp. 230-240.

47. Paris, S.G., Saarnio, D.A. \& Cross, D.R.A., 1986. Metacognitive curriculum to promote children's reading and learning. Australian Journal of Psychology, 38, pp. 107-123.

48. Pintrich, P.R., 1999. The role of motivation in promoting and sustaining self-regulated learning. International Journal of Educational Research, 31, pp. 459-470.

49. Rohman, D.G., 1983. Pre-writing: The stage of discovery in the writing process. In: M. Myers \& J. Gray, eds. Theory and practice in the teaching of composition. Illinois: NCTE, pp. 86-95.

50. Rohman, G., 1965. Prewriting: The stage of discovery in the writing process. College Composition and Communication, 16, pp. 106-112.

51. Scardamalia, M., 1981. How children cope with the cognitive demands of writing. In: C.F. Frederiksen \& J.E. Dominic, eds. Writing: The nature, development and teaching of written communication, Volume 2. Hillsdale, New Jersey: Erlbaum, pp. 81-103.

52. Scardamalia, M. \& Bereiter, C., 1986a. Research on written composition. In: M.C. Wittrock, ed. Handbook of research on teaching. 3rd ed. New York: Macmillan, pp. 778-803.

53. Scardamalia, M. \& Bereiter, C., 1986b. Writing. In: R.F. Dillon \& R.J. Sternberg, eds. Cognition and instruction. Orlando: Academic Press, pp. 59-81.

54. Schunk, D.H. \& Zimmerman, B.J., 1994. Preface. In: D.H. Schunk \& B.J. Zimmerman, eds. Selfregulation of learning and performance: Issues and educational applications. Hillsdale, New Jersey: Lawrence Erlbaum, pp. ix-xi.

55. Schwartz, B. L. \& Perfect, T. J., 2002. Introduction: Toward an applied metacognition. In: T. J. Perfect \& B.L. Schwartz, eds. Applied metacognition. Cambridge: University Press.

56. Sommers, N., 1980. Revision strategies of student writers and experienced adult writers. College Composition and Communication, 31, pp. 378-388.

57. Torrance, M., Thomas, G.V. \& Robinson, E.J., 1999. Individual differences in the writing behaviour of undergraduate students. British Journal of Educational Psychology, 69(2), pp. 189-199.

58. Torrance, M., Thomas, G.V. \& Robinson, E.J., 2000. Individual differences in undergraduate essay writing strategies: A longitudinal study. Higher Education, 39 (2), pp. 181-200.

59. Weinstein, C.E., \& Mayer, R.E., 1986. The teaching of learning strategies. In: M. Wittrock, ed. Handbook of research on teaching. 3rd ed. New York: Macmillan, pp. 315-327.

60. Wellman, H.M., 1985. The origins of metacognition. In: D.L. Forrest-Pressley, G.E. MacKinnon, \& T.G. Waller, eds. Metacognition, cognition and human performance, Volume 1. NY: Academic Press, pp. $1-31$.

61. White, R.T., 1988. Metacognition. In: J.P. Keeves, ed. Educational research, methodology, and measurement: An international handbook. Oxford: Pergamon, pp. 70-75.

62. Zimmerman, B.J.\& Bandura, A., 1994. Impact of selfregulatory influences on writing course attainment. American Educational Research Journal, 31(4), pp. 845-862. 